\title{
The Use of Fantasy in Doris Lessing's Selected Fictions
}

\author{
Sayyed Ali Mirenayat, Elaheh Soofastaei \\ Faculty of Modern Languages and Communication \\ Universiti Putra, Malaysia \\ E-mail address: ali.mirenayat@yahoo.com; ela.soofastaei@yahoo.com
}

Keywords: Fantasy, Language, Reality, Society, Sufism.

\begin{abstract}
Doris Lessing (1919 - 2013) was one of the greatest British writers and the oldest winner to win the Nobel Prize in Literature. Since 1969, she started to use fantasy in her works as a mode of fictional expression. Fantasy is a genre in literature that contains supernatural phenomena in fictional worlds. This paper's central concern is also the use of fantasy in her works. For her, fantasy is a tool used to separate present day reality. Fantasy allows her to cope with themes that could not have been used in realistic works. This paper explores the question of fantasy in Lessing's selected novels.
\end{abstract}

\section{INTRODUCTION}

Until the present time, Lessing's career tries to show a transformation from a socialist realism to the speculative forms to fantasy. In her book series of The Canopus in Argos, Lessing makes a fantasy world which allows her to diagnose the sickliness of human society, to see phenomena which cause discord and disorder. Her first experiment with fantasy is The Golden Notebook (1962) and The Four Gated City (1969) which both are followed by fictions such as Briefing for a Descent into Hell (1971) and The Memoirs of a Survivor (1975). Although many know Lessing's fiction based on Sufism, but she has always rejected her turn to Sufism. Sufism, for her, is then a way of observing the world and of mankind's potential. To Ann Scott, "Lessing's mysticism is not the face of it linked with any sense of a unitive state, of a merging into the Absolute of the Infinite or even with any special experience" (185). For Scott, Lessing does not make a visionary landscape in The Four Gated City. Instead, she talks about countries that can be named although their geographical borders may be unclear.

\section{PHENOMENON OF FANTASY}

One of the more confusing phenomena in science fiction is fantasy. This phenomenon is seen in literature, films and theatre. Fantasy fiction is considered as escapist literature which it did not render a well-observed picture of man who lives in society. Besides Lessing, there are other writers, such as Anthony Burgess and Margaret Atwood who had great experience with the realism, but later turned to fantasy. Fantasy like science fiction is also produced and determined by its social context. Though it might struggle against the limits of this context, it cannot be understood in isolation from it. Lessing believes that science fiction maps our world for us. This genre presents new and inspiring ways about the world to fantasize. It has also stretched the realistic form of the novel and is unquestionably affecting and influencing it.

Fantasy literature transforms the real through its fiction. It does not try to introduce novelty. It lies alongside the axis of the real which is used to present a fantastic realm emphasize its place. Fantasy for Lessing is to be considered a device, a way of distancing present day reality in order to probe and question it. Fantasy is also a mode which allows her to deal with themes like memory, timing, and post-apocalyptic life which could not be dealt with the realistic mode.

Doris Lessing in Briefing for A Descent into Hell (1971), The Summer Before the Dark (1973), and The Memoirs of A Survivor (1974) focuses on more private experiences of an individual and the self-exploration of characters in the privacy of his/her mind. Lessing warns us to this change. She in these fictions also tries to find a language, as a dual function, and a narrative structure that can transfer a convincing union of self and society. Another common aspect of these fictions is the Sufi beliefs in them. They have evidence of Sufism's impact in the writer herself. 
These features are ignored by some critics who note that fantasy is deployed in these fictions but are not accepted.

In Briefing, Charles Watkins is the protagonist who is a middle-aged professor, unable to remember who he is. He just remembers that he has been on a ship and then in a land inhabited by creatures part dog and part rat. The doctors make an attempt to restore his memory, but he refuses to remember. There is a juxtaposition of two worlds in the story in which the outer is the ordinary world of nurses and doctors, and the inner world of the Watkin's mind where he sails the seas and meets weird creatures. While the writer uses her special language in creating these worlds, her persistent undercutting of its possibilities, suggests that she finds it limited, unable to provide the kind of meaning she requires. She comes closest to showing a language close to Charles' knowledge in which he is reborn, then time and space travelling again to his present situation in the novel. Importantly, Lessing dispenses briefly with simple narrative language. She interprets Charles thoughts with the sounds of the external world creating a sense of the distance and tension between the two worlds.

The writer has always been preoccupied with the idea of human beings evolving to a higher level of consciousness. For example, in her two novels of Four Gated City and Briefing, she illustrates Martha, Lynda and Charles seeking for the dimension of madness to become richer. In Memoirs, the narrator, Emily, Gerald, and Hugo go to a new world when they are ready for it. The writer through using fantasy tries to sharpen her dialectic of sameness and difference. She showed how it is impossible for an individual to think differently from the whole he or she is part of. To her, when we dream we are not dream for ourselves alone, neither are our dream worlds familiar only to us.

Fantasy has allowed the writer this freedom. In realism, an empirical sample of Lessing's society is all that is possible. But she uses this mode because she can get beyond a world that she is not limited now to a particular society only. Lessing uses fantasy in her novels to satirize and dissect the political illusions of twentieth century. She tries to show her readers how language is debased when used as a tool of power. Her fantasy novels are rooted in social reality. There are other distinctive features of her novels. Her fantasy worlds are personal but not exclusive; they are imbued with a moral vision and have a marked sensuous quality. Her writing has nearly always been of epic scope and scale. She has involved herself in a wide world of issues ranging from the global to the individual. At the same time, she has paid careful attention to the personal.

The way to deal with the problem of subjectivity that shocking business of being preoccupied with the tiny individual who is at the same time caught up in such an explosion of terrible and marvelous possibilities is to see him as a microcosm and in this way to break through the personal, the subjective, making the personal general. (Preface to The Golden Notebook, p.xii)

The writer does not give up these ideas with her use of fantasy. As a matter of fact, in her earlier fictions, Briefing, Memoirs, the used fantasy was accused of focusing too much on the inner life of an individual. However, these experiences are not private or self-contained. Though they are subjective, it is clear that within the worlds of her novels, subjectivity is a result of social, political, and psychological forces around the individual. But though Lessing places significance on the individual and his perspective, she does not advocate a sick, selfish individualism. For her, "growing up ... is the understanding that one's unique and incredible experience is what everyone shares" (The Golden Notebook, p.xiii).

There is a very definite moral vision that informs her fantasy. But, morality for her has different dimensions which are related to religion and human experience. She has unbounded faith in man's ability to cope with any circumstance. In her novels, she does not draw us a map showing the readers exactly where each empire and planet is positioned. The readers are given only so much detail as to provide the minimum texture for them to comprehend. She allows for a full play of all the various senses. The first sense gives the readers a broad sweep of the landscape and then the readers are lead on to focus on more particular details. 


\section{CONCLUSION}

By using fantasy, Lessing has been able to enhance the subjective and objective dialectic, evolve her own moral code and create rich, complex and sensuous realms. Lessing uses fantasy as a device to distance present day reality in order to probe and question it. Her fantasy is not an avenue for a mythic return to neither a timeless past nor a mode of scape. The realistic content of her fantasy is evident from the fact that there is no radical departure from the socio-political concerns of her fiction. Her novels rehearse the dominant themes of her earlier realist fictions. Her fantasy realms - inner or outer space - are not ideal other worlds. They have a relation close to the real, and by using fantasy she presents these issues in new perspectives.

She not only shows the readers how contemporary society mains an individual but also tries to illustrate how man's greed has wreaked havoc and horror in the world we live. By using fantasy, she shows, interprets and selects reality for the readers. Lessing has no illusions about life, but does not defend any withdrawal from the world. Actually, in her fictions, she reiterates the necessity of social interaction. Her clear understanding of life today does not make her sentimental.

However, she has accomplished more than just a reworking of her earlier concerns in her novel. She tries to incorporate myths, legends, and deals with themes that could not have been dealt with in a realistic text. Lessing conjectures about man's origins and future, life after apocalypse, the reasons for the present condition of the world, life in other galaxies, growth and significance of memory. Using fantasy, she creates realms which have close parallels to our own and but which are different in the way they are constructed.

\section{References}

[1] Lessing, Doris. The Golden Notebook. London: Redwood Press Limited, 1972.

[2] ---, The Four Gated City. London: Granada Publishing Limited, 1973.

[3] ---, Briefing for a Descent into Hell. London: Jonathan Cape Limited, 1971.

[4] ---, The Memoirs of a Survivor. London: The Octagon Press, 1974.

[5] Scott, Ann. "The More Recent Writings: Sufism, Mysticism and Politics", in Notebooks/Memoirs/Archives: Reading and Rereading Doris Lessing, ed. Jenny Taylor, London: Routledge and Kegan Paul, 1982. 